\title{
LA ANGUSTIA TEMPORAL Y LOS REDUCTOS DE PLACER EN LA POESÍA DE BAUDELAIRE
}

\author{
Miguel Ángel MURO \\ Universidad de La Rioja \\ miguel-angel.muro@unirioja.es \\ Y los días se echaron a caminar. \\ Y ellos, los días, nos hicieron. \\ $Y$ así fuimos nacidos nosotros, \\ los hijos de los días, \\ los averiguadores, \\ los buscadores de la vida. \\ (El Génesis según los mayas, \\ en Eduardo Galeano, Los hijos de los días) \\ Oh douleur! ô douleur! Le temps mange la vie. ${ }^{1}$ \\ (Baudelaire, «L'Ennemi», Les fleurs du mal)
}

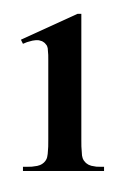

\section{Dimensión dramática de la temporalidad en Baudelaire}

Después del episodio vitalista del Renacimiento, con su exaltación de la belleza y la vida, la ideología de la Contrarreforma volvió a atenazar los ánimos de los creyentes con el miedo a la muerte, sintetizado en el vértigo temporal que prácticamente eliminaba el tiempo de existencia entre la cuna y la sepultura, y reducía al ser a la condición de «un es cansado», como formuló con acierto Quevedo. Algo de la crítica áspera de las Danzas de la Muerte, con su contento por la única justicia hallable en el mundo, la igualación de todos en el último momento, queda en las dos tremendas alegorías de Valdés Leal de la iglesia de la Santa Caridad de Sevilla, pero el mensaje más potente que transmiten es el recordatorio descarnado del señorío de la Muerte, de la privación de la vida, del despojo de la carne, de la belleza, de la vida.

El Romanticismo se sacudió (o intentó sacudirse) esta visión lacerante pero aun así está traspasado por la angustia del tiempo que lleva a la muerte sin el consuelo de un dios que garantice una vida posterior (Pedraza y Rodríguez, 1982: 24-26), aunque en ocasiones sus fábulas, dramas y poemas no cuenten el efecto atormentador de las horas que pasan sino el hecho dramático de la propia muerte de sus protagonistas, como Karl de Moor, Wherter o Atala. El drama romántico está traspasado

\footnotetext{
${ }^{1} \ll--¡$ Oh dolor!, ;oh dolor! Come el Tiempo a la vida».
} 
por esta temporalidad angustiosa, plasmada con frecuencia reveladora en la noción del plazo, el tiempo tasado del que se va descontando parte a parte, hasta que ya no queda nada y se consume y con él se consuma la derrota de las ilusiones, de la felicidad, de la vida: espléndida metáfora o alegoría de la vida, siempre que sea vista desde la derrota.

Baudelaire, como Flaubert, recibe de forma crítica la herencia ideológica y artística del Romanticismo y profundiza en ella acentuando de forma dolorosa la tensión entre el Ideal y el Spleen, entre el impulso elevador hacia lo Infinito, lo Eterno, la Divinidad (o en dimensión más humana: la luz, la compasión por los pobres, el amor sublimado, la creación artística) y la realidad mediocre, dolorosa y angustiante, la inevitable constatación de la estupidez, el mal y el dolor por lo transitorio, a lo que se suma el remordimiento de conciencia por las caídas en el pecado, tensión que, en su resolución negativa, se sustancia en la derrota.

Así, el tiempo cobra en los textos del iniciador de la poesía moderna una dimensión y una intensidad dramáticas, como tema o actante del poema y como protagonista de algunas de sus imágenes más recurrentes; dimensiones que se suman y amalgaman al tiempo que interviene en la construcción de la estructura de muchos de sus poemas que van más allá de la captación del instante, consustancial a la poesía (García Jambrina, 2000: 46; Del Prado, 2011: 40-50; Muro, 2014: 252): paso del tiempo en el poema, diferentes planos temporales (Schlossman, 2011: 686), cierta narratividad (Del Prado, 2011: 34), gerundios que expresan duratividad, tiempo condensado...); muchos de sus poemas son puro movimiento: llegar, abrir, derramar, florecer...

La crítica puso de manifiesto muy pronto la vinculación de Baudelaire con la poesía del Barroco y, en particular, con su visión de la fugacidad de la vida y la acción corrosiva del tiempo. Es conocida también la atracción que las Danzas de la Muerte ejercían en Baudelaire pero no (o no solo) por su intención crítica (en cuanto a revancha de los desheredados contra los poderosos), sino por la fascinación aterradora de la putrefacción y los esqueletos. No hay en Baudelaire «alma dormida» que precise «despertar», ni «seso» que deba ser avivado, como encarece el tópico sapiencial-moral, reelaborado de forma magistral por Manrique, porque el autor francés aparece ya instalado en el programa ominoso y lapidario del barroco que reelabora Quevedo y parece no hallar «cosa en que poner los ojos» que no sea «el recuerdo de la muerte» (en este sentido habla Walter Benjamin de la poesía de Baudelaire como «mímesis de la muerte», 2002: 123), tras la vivencia angustiada del vértigo que produce el paso del tiempo, como expresa con claridad en «Chant d'automne»: «C'était hier l'été; voici l'automne! $»^{2}$. El problema para Baudelaire (y la ventaja para la intensidad emocional de su poesía) es que su propio programa ideológico y vital no llega a encontrar en la religión consuelo que mitigue (y, mucho menos, haga desaparecer) la angustia que le provoca la conciencia de la mortalidad. No hay un Más Allá (o el autor no lo invoca o no se atreve a concebir que esté abierto para él) con un Dios justo o justiciero, paternal o despótico, que garantice otra vida. Es patética, en este sentido, la

\footnotetext{
${ }^{2} \ll$;Ayer era verano; hoy es otoño!».
} 
invocación del final de «Les phares», ese grito repetido por mil centinelas, ese «ardent sanglot» que «vient mourir au bord de votre éternité!»3 .

En todo caso, es esta, la vida conocida, la que ha de servir para hallar la felicidad o conseguir una obra artística memorable, y el tiempo, desgraciada, angustiosamente, la va menguando. Siendo Dante una de las referencias del autor francés, su Comedia ya no puede ser «divina» y queda reducida al Infierno y al Purgatorio (a la nostalgia, como mucho, de un paraíso terrenal): la fe total no es posible y cualquier esperanza no tiene suficiente fundamento y causa dolor; la Beatriz, cuyo amor sirve de aval y motor espiritual a Dante para emprender su viaje de salvación, es en el poema de Les fleurs $d u$ mal que lleva su nombre una dolorosa caricatura de la florentina que aparece burlesca entre «la tropa obscena» de diablos, riéndose del «negro desamparo» del poeta. Un poema clave para calibrar la distancia que separa a Baudelaire de la concepción cristiana de la muerte es el titulado «Le mauvais moine», donde el poeta señala cómo las pinturas de los claustros glorificaban la muerte y expresa el lamento de su propia incapacidad para asumir su condición: «Quand saurai-je done faire / Du spectacle vivant de ma triste misère /Le travail de mes mains et l'amour de mes yeux?» ${ }^{4}$.

$\mathrm{Y}$ es que Baudelaire ve también la vida como una condena. El pensamiento constante de la mortalidad lo convierte en un condenado en el corredor de la muerte, siempre a la espera de la ejecución. Es en «Le masque» donde el poeta expresa con mayor claridad esta concepción: «Elle pleure, insensé, parce qu'elle a vécu! / Et parce qu'elle vit! Mais ce qu'elle deplore / Surtout, ce qui la fait frémir jusqu'aux genoux, / C'est que demain, hélas! il faudra vivre encore! / Demain, apres-demain et toujours! Comme nous!» 5 .

\section{La expresión de la angustia por la acción del tiempo}

Son varios los poemas en los que, a lo largo de Les fleurs du mal, Baudelaire expresa con claridad, de forma descarnada la angustia que le produce la conciencia aguda del quehacer corrosivo del tiempo, al que individualiza como fuerza o actante letal de la vida y al que nombra de forma directa o casi transparente.

En el soneto «L'ennemi», Baudelaire recorre en dos cuartetos el arco temporal que va de la juventud al otoño de su vida, mientras el último cuarteto es la expresión vehemente de esa angustia: «- O douleur! ó douleur! Le Temps mange la vie, / Et l' obscur Ennemi qui nous ronge le coeur / Du sang que nous perdons croit et se fortifie!» ${ }^{6}$.

Idea similar vuelve a presidir «L'Irréparable», donde el oscuro, vigilante y funesto Enemigo recibe esta nueva denominación, si bien su actividad y efectos son los mismos: «L'Irréparable ronge

\footnotetext{
${ }^{3}$ «ardiente sollozo [...] que muere en el borde de vuestro ser eterno!».

4 «¿Cuándo sabré hacer yo / con el vivo espectáculo de mi triste miseria / el amor de mis ojos y el quehacer de mis manos?».

5 «Ella llora, insensato, llora porque ha vivido! / ¡Y llora porque vive! Pero lo que le duele / más, y hasta las rodillas estremecerse le hace / es que mañana ¡ay!, ¡aún habrá de vivir! / ¡Y pasado, y al otro, y siempre...! --¡Cual nosotros!».

${ }^{6}$ «-¡Oh dolor! ¡Oh dolor! ¡Come el Tiempo a la vida', / y el oscuro Enemigo que el corazón nos roe / se fortifica y crece robándonos la sangre!».

«vigilante y funesto enemigo» vuelve a llamar Baudelaire al tiempo en «Le voyage», cerrando ya el poemario.
} 
avec sa dent maudite / Notre áme, piteux monument, / Et souvent il attaque, ainsi que le termite, / Par la base le batiment. / L'Irréparable ronge avec sa dent maudite!»7

En «Le goût du néant» la expresión es todavía más sencilla y más directa: «Et le Temps m'engloutit minute par minute. $\rangle^{8}$, como tormento que se suma (o compendia) la pérdida de la Esperanza y del gusto del amor.

Es interesante, a este respecto, notar que la imagen de sufrir la devoración no se liga únicamente a la acción del tiempo sino que tiene un espectro más amplio, lo que viene a mostrar su condición medular en la concepción de Baudelaire. Así, la hallamos también vinculada al Ideal en «L’aube spirituelle», como «l'Ideal rongeur», el remordimiento de conciencia que acomete al libertino al aflorar la aurora, y al propio Remordimiento en «L'irréparable», donde se viste con la imagen de la gusanera, tan propia de Baudelaire: «Pouvons-nous étouffer le vieux, le long Remords, / Qui vit, s'agite et se tortille, / Et se nourrit de nous comme le ver des morts, / Comme du chêne la chenille? / Pouvons-nous étouffer l'implacable Remords?» ${ }^{9}$, remordimiento que se asimilará al Tiempo y también será llamado, como él, «viejo enemigo», roedor del alma («L’Irréparable ronge avec sa dent maudite / Notre âme») y del que se señala la cualidad devoradora y glotona «como una cortesana» (ligando Tiempo, Placer y Pecado) y se aporta la novedad sobre las imágenes anteriores de la acción constante y paciente («comme la fourmi») y de roer desde la base («ainsi que le termite») que no se dice del Tiempo. En el poema en prosa «Un caballo pura sangre» de Le Spleen de París, son el Tiempo y el Amor quienes actúan de forma conjunta sobre una mujer fea y deliciosa («Le Temps et l'Amour l'ont marquée de leurs griffes et lui ont cruellement enseigné ce que chaque minute et chaque baiser emportent de jeunesse et de fraîcheur.»), sin llegar, no obstante, a destruir su encanto: «Le Temps et l'Amour l'ont vainement mordue à belles dents; ils n'ont rien diminué du charme vague, mais éternel, de sa poitrine garçoniere» ${ }^{10}$.

Pero va a ser en «L'horloge» donde Baudelaire plasme de forma casi tradicional el tópico moral del «memento mori», sustanciando en paso del tiempo en el reloj, el objeto inventado por el ser humano para medirlo y con ello recordar constantemente su condición mortal. El reloj adquiere la condición de dios en la concepción de Baudelaire («Horloge! dieu sinistre, effrayant, impasible, / Dont le doigt nous menace et nous dit: "Souviens-toi!" $\left.{ }^{11}\right)$, aunque le correspondería mejor la de ídolo o representante del verdadero dios, el Tiempo. Como en otros aspectos importantes de su poesía, repite Baudelaire esta imagen sencilla y potente en otros poemas, como «Le rêve d'un curieux»: «Plus allait

\footnotetext{
${ }^{7}$ «Lo Irreparable roe con su diente maldito / nuestra alma, pobre monumento, / y a menudo, lo mismo que la termita, ataca / el edificio por su base. / ¡Lo Irreparable roe con su diente maldito!».

8 «Y el tiempo me devora minuto por minuto».

9 «¿Podemos sofocar nuestro Remordimiento, / que se retuerce, agita y vive, / y nos devora igual que a los muertos el verme, / cual las orugas a los robles? / ¿Podemos sofocar el cruel Remordimiento?».

10 «El Tiempo y el Amor la han marcado con sus garras y le han enseñado cruelmente lo que cada minuto y cada beso se cobran en juventud y en frescura.»), «En vano el Tiempo y el Amor la mordieron con todos sus dientes; en nada disminuyeron el encanto vago, pero eterno, de su pecho púber.» (1999: 135). Las traducciones de L'Spleen de Paris las haré a partir de la edición de Francisco Torres Monreal, El esplín de París (Pequeños poemas en prosa). Madrid: Alianza, 1999.

11 «Reloj!, siniestro dios, impasible, horroroso, / cuyo dedo amenaza y ¡Acuérdate! nos dice».
} 
se vidant le fatal sablier.» ${ }^{12}$ Es curioso, sin embargo, que un poeta tan preocupado por la temporalidad no aluda, cuando reflexiona y escribe sobre el reloj, a la formulación tétrica que acompaña a muchos de ellos, referida a las horas: «Vulnerant omnes, ultima necat», «Todas hieren, la última mata».

\section{Los agentes ejecutores del Tiempo}

La enfermedad y el spleen son la plasmación más concreta y realista de los agentes del Tiempo en Les fleurs du mal.

Humana, casi sin filtro poético, es la aprehensión que expresa el yo poético en «Réversibilité» por la pérdida de la salud y de la belleza: «Ange plein de santé, connaissez-vous les Fièvres [...]? / Ange plein de beauté, connaissez-vous les rides, / Et la peur de vieillir, et ce hideux tourment / De lire la secrete horreur du dévouement / Dans des yeux où longtemps burent nos yeux avides? / Ange plein de beauté, connaissez-vous les rides?» ${ }^{13}$ Esta aprehensión se irá adueñando de las últimas páginas de sus Journaux intimes en los que irá dejando constancia, cada vez con más urgencia, de la cercanía de la enfermedad y del apremio por frenarla mediante el trabajo, la higiene y una conducta ascética, para poder llevar a cabo sus últimos planes vitales y artísticos.

El spleen, entendido no como el macro concepto de todo lo negativo del mundo y de la vida, opuesto al Ideal, sino como el ennui, el Hastío, el Aburrimiento, la depresión profunda por la falta de estímulos en un mundo burgués sin color, es considerada por Baudelaire como una enfermedad terrible pero en ella es de signo distinto la acción del tiempo y la angustia que provoca. En la enfermedad y el envejecimiento se percibe el transcurrir corrosivo del tiempo; en el Hastío, por el contrario, el tiempo se detiene hasta hacer sentir su peso al condenado que soporta a duras penas la vida, como el íncubo que oprime el pecho de la durmiente en «La pesadilla» de Füssli: el tiempo parece adensarse en los poemas del Hastío hasta expulsar el aire y ahogar al yo poético.

En «De profundis clamavi» lamenta el poeta el «spleen», el hastío que hace odiosa la vida, metaforizado en un universo señoreado seis meses por la noche horrenda que recuerda al Caos y otros seis por un sol gélido, y envidia la suerte de las fieras que, inconscientes, pueden dormir, mientras a él le lacera el lento discurrir del tiempo: «Tant l'écheveau du temps lentement se dévide!» ${ }^{14} \mathrm{El}$ poeta vuelve sobre la misma idea en «Spleen» (LXXVI), pero vinculando ahora el paso interminable de las horas con la inmortalidad: «Rien n'égale en longueur les boiteuses journées, / Quand sous les lourds flocons des neigeuses années / L'ennui, fruit de la morne incuriosité, / Prend les proportions de l'immortalité.» $^{15}$. La imagen del gusano devorador, clave en el imaginario de Baudelaire, vuelve a aparecer en este poema en el que los recuerdos que se pierden laceran al poeta: «Je suis un cimetière

\footnotetext{
12 «Más del reloj fatal la arena iba cayendo».

13 «Ángel de salud lleno ¿Conoces tú las Fiebres [...]? / Ángel de beldad lleno ¿Y el miedo a las arrugas, / a envejecer, la horrible tortura de leer / el secreto terror del desvelo en los ojos / donde ávidos bebieron nuestros ojos ha tiempo? / Ángel de beldad lleno ¿Y el miedo a las arrugas?».

14 «iTan lenta la madeja del tiempo se devana!».

15 «Nada es igual de lento que las cojas jornadas, / cuando bajo pesados copos de años nevosos, / el hastío, ese fruto de la falta de afanes, / toma las proporciones de la inmortalidad».
} 
abhorré de la lune, / ou comme des remords se traînent de longs vers / Qui s'acharnent toujours sur mes morts les plus chers» ${ }^{16}$.

\section{Helmintos y vampiros: imágenes del tiempo devorador}

Son varias, y muy plásticas, las imágenes recurrentes del imaginario de Baudelaire que sustancian esa acción de lima, de devorar (el tiempo «come», «roe», «roba», «chupa» la vida).

Se trata, en unos casos, de los helmintos, los gusanos que parasitan el intestino y lo infectan y necrosan que, como bien señala Martínez del Merlo (desde la Poética del Imaginario de Gilbert Durand) transmiten la imagen del «tiempo devorador y de la muerte amenazante» (Baudelaire, 1995: 77), aunque más bien habría que decir la muerte que labora incesante. Pero, sobre todo, están los gusanos que devoran los cadáveres que aparecen, como un rasgo de identidad de Baudelaire a lo largo de todo el poemario, en el poema XXIV («et je grimpe aux assauts, / Comme après un cadavre un coeur de vermisseaux ${ }^{17}$ ), en $«$ La carrogne» 0 en «Le poison».

El vampiro es otro de los símbolos que Baudelaire emplea para captar la imagen del tiempo devorador. Remite a las arpías y sirenas que también son evocadas en algunos de sus versos y enlaza con el oscuro gusto romántico por este ser (uno de cuyos hitos creativos, como es bien sabido, es The Vampyre de Polidori, mientras que antecede en varias décadas al Drácula de Bram Stoker (1912), subrayando y afirmando sus connotaciones eróticas y mortíferas, si bien, le son adjudicadas en este caso a la mujer y no al hombre. Es muy potente, a este respecto, la imagen de la saliva que muerde con que culmina «Le poison» (tan alejada del gozo festivo de los poemas de Las mil y una noches, donde la saliva de la amada se compara al vino y embriaga como él).

\section{El movimiento y el tiempo}

El movimiento convoca al tiempo en la imaginación poética de Baudelaire con connotaciones intranquilizadoras. En el poema «Les hiboux» el poeta escribe que el búho «Leur attitude au sage enseigne / Qu'il faut en ce monde qu'il craigne / Le tumulte et le mouvement» ${ }^{18}$.

Los «Bohémiens en voyage» («Los gitanos en el camino») son en Baudelaire el emblema del nómada eterno que en el Romanticismo encarnaban el Holandés Errante o el Judío Errante, condenados, como Caín, a vagar sin fin por el mundo. Podría parecer que se opone a este arquetipo el viaje imaginado y deseado por el poeta que causa placer («Parfume exotique», «Le chevelure») porque evade de la realidad y, frente al nomadismo sin fin de los anteriores, conlleva un destino, un lugar donde arribar y detener el viaje. Pero, en realidad, el hecho de que estos sean deseos insatisfechos subraya de forma dolorosa la primacía de los errantes malditos.

\footnotetext{
16 «Yo soy un cementerio que aborrece la luna, / donde largos gusanos, como remordimientos, / se arrastran y a mis seres más queridos descarnan».

17 «y me lanzo al asalto, / como tras de un cadáver un coro de gusanos».

18 «Al sabio enseña su actitud / que en este mundo hay que temer / el movimiento y el tumulto».
} 
La noción de abismo es una de las metáforas más obsesivas de Baudelaire, símbolo del tiempo infernal opuesto al paradisiaco (Poulet, 1949: 336-337), y con frecuencia sus versos hablan de rodar hasta él, quedarse temblando en su borde o caer aterrado al vacío o, por el contrario, de hundirse con voluptuosidad en él es también recurrente en el poeta francés («L’homme et la mer», «Don Juan aux enfers», «Duellum», «Le poison») y envuelve el temor ante lo inaprehensible y, en último extremo, ante lo infinito que, en Baudelaire, se con-funde con lo eterno, sin que ninguna de las dos nociones pueda ser aceptable.

Junto a las anteriores se da también en esta poesía una importancia grande al dinamismo de las acciones. Baudelaire entiende y percibe la vida en desarrollo y es frecuente que señale acciones que transcurren, lo que hace que, de forma indirecta, sugieran tiempo que pasa.

Es el cuerpo de «La Géante» que desearía ver floreciendo y creciendo, «le magnifique fleuve / de tes pleurs aboutit dans mon coeur soucieux» («Le masque»), la belleza que surge, derrama perfumes, va sembrando la dicha o los desastres y camina sobre los muertos («Hymne a la beauté»), las jubilosas riberas que se despliegan y el perfume de verdes tamarindos que embriaga al poeta y se mezcla con las canciones marineras en el viaje de «Parfume exotique», la cabellera de la amada sentida como un puerto rumoroso en el que bebe el alma del poeta, «ou les vaisseaux, glissant dans l'or et dans la moire, / Ouvrent leurs vastes bras pour embrasser la gloire / D' un ciel pur ou frémit l'éternelle chaleur.» ${ }^{19}$, la noche que se va espesando como un tabique («Le balcón») o que fluye como un río sobre París («Confession»), la tristeza que asciende como el mar hasta el arrecife («Semper eadem» y «Causerie»), el corazón que reflorece por un nuevo amor («XLII»), los ojos que caminan ante el poeta y lo guían («Le flambeau vivant»), el ángel que, en la aurora, se despierta en la bestia dormida del libertino y contempla abrirse el cielo como una sima en la que hundirse («L'aube spirituelle»), la flor que se evapora como un incensario, los sones y aromas que giran en el aire, el vértigo desmayado de un recuerdo intenso («Harmonie du soir»), los pensamientos que despliegan sus alas y echan a volar tocados por un perfume, los recuerdos que giran en el aire y llevan hasta el borde de la sima donde yace un viejo amor rancio ya («Le flacon»), la ponzoña hechizadora que manan los ojos verdes de Marie Daubrun («Le poison»), el Espíritu del poeta que, hecho aromas, ascenderá hasta la amada, como hacia la Virgen María («À une madone») o el sol que chorrea en la tarde («XCIX»).

Son también, en un sentido cercano, los estremecimientos de los cuerpos («Le masque»), los deseos del poeta que parten en caravana hacia la deseada Jean Duval («Sed non saciata») y después los sueños que vienen en tropel a saciar su sed en las simas amargas de los ojos de Marie Daubrun («Le poison», y los movimientos de la carroña que se descompone lenta, inapelablemente al sol en «Une charogne», que suda venenos, que se abre como una flor de la que salen negras tropas, que sube o desciende como una ola o se remonta como burbujas, que parece multiplicarse, que produce una

\footnotetext{
19 «...y en donde los bajeles, flotando en muaré y oro, / abren sus vastos brazos para abrazar la gloria / de un cielo puro donde vibra el calor eterno».
} 
extraña música, como de viento y agua que corren o grano que se zarandea rítmicamente en la cribadora, mientras zumban sobre ella los insectos. ${ }^{20}$

\section{El eje vertical de la imaginación de Baudelaire}

Consideradas en conjunto estas imágenes, se marca con claridad un esquema o eje vertical, ascendente-descendente (Durand, 1982: 55) que parece vertebrar buena parte de la imaginación poética de Baudelaire.

El ascenso, el impulso ascensional se explicita con la vitalidad del éxtasis en «Le vin des amants» ( «Aujoud'hui l'espace est splendide! / Sans mors, sans éperons, sans bride, / Partons a cheval sur le vin / Pour un del féerique et divin!» ${ }^{21}$ ) y aparece también vinculado al vuelo del ave, como en «Un voyage à Cythère» («Mon coeur, comme un oiseau, voltigeait tout joyeux / Et planait librement a l'entour des cordages. / Le navire roulait sous un ciel sans nuages, / Comme un ange enivré d'un soleil radieux ${ }^{22}$ ).

Pero el ascenso y el vuelo están acechados e infectados por el peso de la miseria y el dolor (Citerea, la isla de la diosa del amor es vista como un lugar triste y negro) y son muy numerosas las muestras de la caída y, sobre todo, la caída en el pecado (frase hecha del lenguaje religioso) que plasma de forma expresiva en «L'irremédiable»: «Une Idée, une Forme, un Être / Parti de l'azur et tombé / Dans un Styx bourbeux et plombé / où nul oeil du Ciel ne pénètre» ${ }^{23}$.

\section{Los remedios contra el tiempo que mata}

Frente al tiempo infernal, del horror y la infelicidad, se encuentra el paradisíaco, el de la infancia, el de la felicidad, el tiempo eterno, extático, vinculado en la imaginación de Baudelaire con el espacio que se extiende (Poulet, 1949: 327-335). Es este tiempo el que Baudelaire convoca y persigue para exorcizar al tiempo que lo angustia, con distintos (re)medios para acceder al paraíso, al paréntesis sin tiempo o al tiempo placentero, aunque ninguno de ellos llega a ser tan poderoso como para proporcionar al poeta ni una calma duradera ni, por supuesto, una esperanza de triunfo.

La imagen del mar vincula y agrupa por el placer tres de estos remedios: el viaje, la música y la sensualidad.

El viaje, la ida o huida hacia otro lugar es para Baudelaire también la salida fuera del tiempo que consume. El mar, el océano que convocan la angustia del tiempo cuando son considerados por la imaginación del poeta en su condición de infinitos y eternos, cuyos abismos aterran, pasan a mitigar

\footnotetext{
${ }^{20}$ Llama la atención que lo esencial de los movimientos de esta descripción reaparezca en un poema de signo muy distinto, como es «À une madone», donde se lee: «Ta Robe, ce sera mon Désir, frémissant, / Onduleux, mon Désir qui monte et qui descend, / Aux pointes se balance, aux vallons se repose» («Tu Vestido será mi Anhelo estremecido / ondulante, mi Anhelo que desciende y que sube / se columpia en las cimas y en los valles reposa.»).

${ }^{21}$ «Espléndido es hoy el espacio! / ¡Sin freno, sin bridas ni espuelas, / a lomos del viento [sic] vayamos a un mágico cielo divino!».

22 «Mi corazón, cual ave, gozoso aleteaba / y planeaba libre en torno a los cordajes; / el navío bogaba bajo un cielo sin nubes, / tal ángel embriagado por un radiante sol».

${ }^{23}$ «Una Idea, una Forma, un Ser / que de lo azul cae a una Estigia / plúmbea y fangosa, en que ningún / ojo del cielo ha penetrado».
} 
estos sentimientos cuando son sentidos como cunas gigantes que arrullan el espíritu, como ocurre en «Moesta et errabunda»: «La mer, la vaste mer, console nos labeurs! / Quel démon a-doté la mer, rauque chanteuse / Qu'accompagne l'immense orgue des vents grondeurs, / De cette fonction sublime de berceuse? / La mer, la vaste mer, console nos labeurs!» ${ }^{24}$.

Algo de esta condición posee también la música. Como ese mar convocado en «Moesta et errabunda», que arrulla al poeta, en «La musique»: «La musique souvent me prende comme une mer!» y el poeta escala por el dorso de las olas y vibra como un bajel zarandeado, «Le bon vent, la tempête et ses convulsions / Sur l'immense gouffre / Me bercent», aunque también hay momentos de quietud que transmiten el peso del tiempo: «D'autres fois, calme plat, grand miroir / De mon désespoir!».

Como se comprueba en «Le chevelure», la belleza sensual de la melena suelta de la amada, vista como un océano inmenso, donde se subsume el real, el que provoca la angustia por su infinitud y sus abismos, transporta al poeta a un puerto paradisíaco donde cesan los afanes (el espíritu se mece), porque la amada es «L'oasis o je réve, et la gourde / ou je hume à longs traits le vin du souvenir» ${ }^{25}$. Aunque también lo será el sentimiento menos sensual y más puro, cuando se abre el ciclo de poemas dedicado a la sra. Sabatier y escriba en «Semper eadem»: «Laissez, laissez mon coeur s'enivrer d'un mensonge, / Plonger dans vous beaux yeux comme dans un beau songe / Et sommeiller longtemps a l'ombre de vos cils!» ${ }^{26}$.

La belleza (con su componente intemporal) es también un lenitivo contra el peso insoportable del tiempo. Flaubert también lo sentía así, cuando escribía: «La vida es una cosa tan repugnante, que el único medio de soportarla es evitarla. Y se la evita viviendo en el Arte, en la búsqueda incesante de lo Verdadero, dado por lo bello.» o «El único modo de soportar la existencia es revolcándose en la literatura como en una orgía perpetua.» El final de «Hymne à la beauté» resuelve las anhelantes pesquisas que el poeta ha ido desplegando en las estrofas anteriores sobre el origen de la belleza volviendo su atención hacia lo que verdaderamente importa: «De Satan ou de Dieu, qu'ímporte? Ange ou Sirene, / Qu' importe, si tu rends, -- fée aux yeux de velours, / Rhythme, parfum, lueur, ô mon unique reine! -- L'univers moins hideux et les instants moins lourds?» ${ }^{27}$.

El recuerdo es otro de estos febles remedios contra la acción devastadora, ladrona y vampírica del tiempo. Baudelaire expresa su capacidad «d'évoquer les minutes heureuses» ${ }^{28}$ («Le balcón») y recurre a él para recobrar momentos en que fue feliz: la madre (Sochorcová, 2011), la infancia, Jeanne Duval, antes de que el tiempo los borre convirtiéndolos en «El fantasma» de lo que fue hermoso. En «El perfume» manifiesta con claridad que el goce radica en el recuerdo: «Charme profond, magique,

\footnotetext{
24 «La mar, la inmensa mar, nuestra labor consuela! / ¿Qué Demonio a la mar, cantante enronquecida, / que acompaña el gran órgano de los vientos fragosos, / le ha dado esta sublime función de arrulladora? / ¡La mar, la inmensa mar, nuestra labor consuela!».

25 «el oasis en que sueño, y el odre / del que aspiro a oleadas el vino del recuerdo».

26 «Deja, deja que mi alma se embriague en la mentira, / y se hunda en tus ojos como en bello sueño / y largo tiempo duerma al pie de tus pestañas!».

27 «De Satán o de Dios ¿Qué importa? Ángel, Sirena, / ¿qué importa si tú --hada de ojos de terciopelo-- / vuelves --ritmo, perfume, luz, ;oh mi única reina!-- / menos horrible el mundo, los instantes más leves?».

28 «Je sais l'art d'évoquer les minutes heureuses».
} 
dont nous grise / Dans le présent le passé restauré! / Ainsi l'amant sur un corps adoré / Du souvenir cueille la fleur exquise.» ${ }^{29} \mathrm{En}$ «El retrato» el poeta francés se sirve del tópico del tiempo que huye, tan caro a renacentistas y barrocos, para, frente a estos, sublevarse contra el tirano. No se trata ya de que la amada coja el «dulce fruto» de su «edad dorada», antes de que el viento marchite «la hermosa cumbre», ni de aceptar que todo cuanto fue bello y placentero se volverá «en polvo, en un humo, en tierra, en sombra, en nada», sino de sublevarse y atrincherar el tesoro en la memoria, retando al Tiempo, «injurieux vieillard» que «chaque jour frotte avec son aile rude», el dibujo pálido que queda de «De tout le feu qui pour nous flamboya»: «Noir assassin de la Vie et de l' Art, / Tu ne tueras jamais dans ma mémoire / Celle qui fut mon plaisir et ma gloire!» ${ }^{30}$ Pero el poeta no se plantea, no quiere plantearse que el recuerdo es, en esta guerra, una posición defensiva débil que resistirá solo cuanto resista su defensor, asediado a su vez por el olvido. Aquí no existe el consuelo de la fama ni mucho menos la creencia tenaz en un amor constante que desafía a la propia muerte, como en Omar Jayyam o en Quevedo. Algo parecido planteará Baudelaire en el final del poema «Una carroña». Como quien busca una salida a la desolación, a la desesperación de la pérdida, de la desaparición, el poeta ahonda en una imagen detallada y mantenida de la putrefacción de un cuerpo de animal a pleno sol en un camino. Los versos suponen un tour de force para exprimir lo desagradable del hecho, de la imagen y sonido de esa carroña, para impedir al lector cualquier escapatoria de lo que sucede con el cuerpo una vez que se convierte en cadáver (en una actitud semejante a la de ascetas como Malón de Chaide y los predicadores terribles de la Semana Santa católica en España hasta hace pocas décadas). Pero si Baudelaire insiste tanto en grabar a fuego en la imaginación del lector ese proceso repugnante no es (solo) por regodeo ante lo asqueroso (categoría que adoptaron con gusto los románticos), sino por preparar mejor el camino a los versos últimos, verdadera profesión de fe ideal, épica-heroica. Si para el Barroco aun la belleza más hiperbólica terminaba consumida y desvanecida en la «nada» del soneto de Góngora, Baudelaire reivindica la persistencia de la forma en la memoria.

Y, sin embargo, el recuerdo, como no podía ser de otro modo en Baudelaire, no tiene siempre el brillo de algo maravilloso. En «Le flacon» el poeta da un quiebro inesperado en la descripción de los pensamientos y sensaciones que evoca un perfume para desembocar en un recuerdo particular al que el alma es empujada, como al borde de una sima: «le cadavre spectral / D'un vieil amour ranci, charmant et sépulcral.» ${ }^{31}$

Baudelaire es un poeta que ama el quiebro sorpresivo y la paradoja. La muerte (que hace valiosa la vida y cuya latencia aterró a Baudelaire gran parte de su vida) será también uno de los remedios para escapar de los rigores de la existencia porque la certeza de su llegada, y con ella el final de los suplicios, da ánimos para soportar el día a día («C'est la Mort qui console, hélas! et qui fait vivre» ${ }^{32}$ ), pero no solo porque tenga el don de acabar con las penalidades de los pobres ( «La mort des pauvres», donde

\footnotetext{
29 «iHondo y mágico encanto, del que embriaga / restaurado el pasado en el presente! / Así el amante en un cuerpo adorado / coge la flor selecta del recuerdo».

${ }^{30}$ Asesino del Arte y de la Vida, / ¡No matarás jamás en mis recuerdos / a la que fue mi gloria y mi placer!

31 el espectral cadáver / de un viejo amor ya rancio, sepulcral y hechicero.

${ }^{32}$ La Muerte es quien consuela, y jay!, quien hace vivir.
} 
todos podemos ser incluidos), sino también porque Baudelaire, hacia el final de su poemario, la entiende como el umbral hacia lo desconocido: «C'est le portique ouvert sur les Cieux inconnus!» ${ }^{33}$, idea o creencia con la que culminará Les fleurs du mal con sus conocidos versos:

\footnotetext{
O Mort, víeux capitaine, il est temps! levons l'ancre!

Ce pays nous ennuie, ô Mort! Appareillons!

$\mathrm{Si}$ le ciel et la mer son noirs comme de l'encre,

Nos coeurs que tu connais sont remplis de rayons!

Verse-nous ton poison pour qu'il nous réconforte! Nous voulons, tant ce feu nous brûle le cerveau, Plonger au fond du gouffre, Enfer ou Ciel, qu'importe?

$\mathrm{Au}$ fond de l'Inconnu pour trouver du nouveau! ${ }^{34}$
}

Pero, mientras se encara lo desconocido que, con toda seguridad, habría de ser nuevo para el que muere, queda la posibilidad de aceptar la construcción cultural e ideológica clásica (grecolatina y dantesca) del Más Allá e imaginar en ella a un héroe mítico abstraído en sí mismo, altivo. Don Juan en los infiernos podría ser en Baudelaire el emblema exorcizante del temor a la muerte: ese héroe que, surcando la Estigia, permanece impasible, sin mostrar ni interés ni temor por nada.

\section{La agudización de la angustia temporal en Le Spleen de París y el pacto con el enemigo en los}

\section{Journaux intimes}

Los poemas en prosa de Le Spleen de París muestran una clara agudización de los temores de Baudelaire a la enfermedad y la decadencia física y mental, lo que hace que el poeta continúe en estas nuevas páginas su obsesión temporal, en ocasiones para reformular algo ya expuesto en Les fleurs, pero en otras para darle alguna novedad.

Quizá la formulación más explícita de la condición angustiosa del tiempo, («la terrible loi du Temps, «la terrible ley del Tiempo», como la nombra en «Les dons des fées» («Los dones de las hadas») se dé en el poema en prosa de este libro, «La chambre doublé» («La estancia doble»), donde el poeta experimenta un momento de placer y felicidad y constata que en él: «Le temps a disparu; C'est l’Éternité qui règne, une éternité de délices.» (Baudelaire, 1975: 281) ${ }^{35}$, pero el sueño dura poco porque:

\footnotetext{
${ }^{33}$ ¡Es el pórtico abierto sobre cielos ignotos!

${ }^{34}$ ¡Oh Muerte! ¡Oh capitán! ¡Tiempo es ya! ¡Alzad el ancla!

Nos hastía esta tierra, ¡Oh muerte! ¡Aparejemos!

¡Si son negros los cielos y la mar cual la tinta,

nuestros pechos ya sabes que están llenos de rayos!.

¡Viértenos tu veneno y que él nos reconforte!

¡Queremos, tanto el fuego los cerebros nos quema,

en el abismo hundirnos, ¿Cielo, Infierno, qué importa?,

al fondo de lo ignoto para encontrar lo nuevo!

35 «El Tiempo se ha evaporado; la eternidad, la eternidad es aquí reina, una eternidad de delicias.» (Baudelaire, 1999: 39).
} 
Oh! Oui! Le Temps a reparu; le Temps règne en souverain maintenant; et avec le hideux vieillard este revenu tout son démoniaque cortège de Souvenirs, de Regrets, de Spasmes, de Pueurs, d'Angoisses, de Cauchemars, de Colères et de Névroses.

Je vous assure que les secondes maintenant sont fortemente et solennellemente accentuées, et chacune en jaillisant de la pendule, dit: — «Je suis la Vie, l'insupportable, l'implacable Vie!»

Il n'y a qu'une Seconde dans la vie humanine que ait misión d'annocer une bonne nouvelle, la bonne nouvelle qui cause à chacun une inexplicable peur.

Oui! Le Temps règne; il a repris sa brutale dictature. Et il me pousse, comme si j'étais un boeuf, avec son doublé aiguillon. — «Et hue donc! bourrique! Sue donc, esclave! Vis donc, damné!» (Baudelaire, 1975: $281-282)^{36}$

Otro de sus textos, el célebre «Enivrez-vous» («Emborrachaos») viene a resumir, como en una receta magistral, parte de estos lenitivos que ofrecía en Les fleurs, a los que ahora se añade el vino (como hubiera podido nombrar el opio o la absenta):

Il faut être toujours ivre. Tout est là: c'este l'unique question. Pour ne pas sentir l'horrible fardeau du Temps qui brise vos épaules et vous penche vers la terre, il fau vous enivrer sans trêve. $337)^{37}$.

Mais de quoi? De vin, de poésie ou de vertu, à votre guise. Mais enivrez-vous. (Baudelaire, 1975:

Aparece también en este librito otra posibilidad que extrañamente no se daba en Las flores, la de matar al matador, la de matar al tiempo. La expresión hecha, tan simple cuando la decimos sin pensar, es tomada por Baudelaire en su literalidad al final de «Portraits de maîtresses» («Retratos de amantes») y, acto seguido, al principio de «Le galant tireur» («El tirador galante»). En el primer poema, los veteranos de la vida alegre que han contado y reflexionado sobre sus amantes, «on fit apporter de nouvelles bouteilles, pour touer le Temps qui a la vie si dure, et accélérer la Vie qui coule si lentement.» (Baudelaire, 1975: 349) ${ }^{38}$; y en el segundo, un marido comenta a su esposa el deseo de disparar algunas balas en un campo de tiro cerca del cual están «para matar el Tiempo» y le pregunta de forma retórica: «Tuer ce monstre-là, n'est-ce pas l'occupation la plus ordinaire et la plus légitime de chacun?» (Baudelaire 1975: 349) ${ }^{39}$.

Hay otra novedad más en Le spleen con respecto a Les fleurs de mayor alcance que tiene que ver con la eternidad como ausencia de tiempo o como un tiempo tan detenido que excluye la propia noción de tiempo. Ya lo veíamos en «La chambre double» y el poeta vuelve sobre él, con mayor sutileza, en «L'horloge», «El reloj», donde el tiempo se detiene en los ojos de la amada en los que el poeta advierte

\footnotetext{
36 «¡Oh sí!, el Tiempo ha vuelto; el Tiempo reina ahora soberano, y con este viejo horrible ha vuelto todo su demoníaco cortejo de Recuerdos, Pesares, Espasmos, Miedos, Angustias, Pesadillas, Cóleras y Neurosis.

En estos momentos, os lo aseguro, los segundos se acentúan con fuerza, con solemnidad, y uno tras otro van diciendo, al saltar del péndulo: « ¿La vida soy, la insoportable, la implacable Vida!».

Sólo existe un Segundo en la vida humana, con la misión de dar una buena noticia, la buena nueva que a todos causa un miedo inexplicable.

¡Sí! ¡El Tiempo es rey! ¡El Tiempo ha reanudado su despiadada dictadura! Y me empuja, como a un buey, con su doble aguijón. — «iArre, borrico, arre! ¡Suda, esclavo! ¡Sigue viviendo, condenado!» (Baudelaire, 1999: 39 y 40).

${ }^{37}$ «Hay que estar siempre borracho. Ésa es la clave; ésa la única cuestión. Para no sentir la horrible carga del Tiempo que os rompe los hombros y os inclina hacia el suelo, tenéis que emborracharos sin tregua.

¿De qué? De vino, de poesía, de virtud, a vuestro antojo. Pero emborrachaos.» (Baudelaire, 1999: 124).

38 «pidieron más botellas, para matar el Tiempo que tiene la vida tan dura y acelerar la Vida que con tanta lentitud discurre.» (1999: 144).

39 «¿Matar a ese monstruo no es acaso la ocupación más habitual y legítima de todos nosotros?» (1999: 145).
} 
«je vois toujours l'heure distinctement, toujours la même, une heure vaste, solennelle, grande comme l'espace, sans división de minutes ni secondes, - une heure immobile qui n'est pas marquée sur les horloges, et cependant légère comme une soupir, rapide comme un coup d'oeil.» (Baudelaire, 1975: 299-300 $)^{40}$, tan opuesta a las horas de plomo de los poemas del «Spleen» de Les fleurs du mal. Si algún inoportuno, dice el poeta, le preguntara qué busca o ve en esos ojos, no vacilaría en responder: «Il est l’Éternité» («jes la Eternidad!»). «L’invitation au voyage» («Invitación al viaje») recupera el anhelo de Baudelaire de alcanzar el placer por el ensueño del viaje (como en «La chambre double» lo era por el sueño) y de nuevo el tiempo retrocede en su imperio: «Oui, c'est dans cette atmosphère qu'il ferait bon vivre, — là-bas, où les heures plus lentes contiennent plus de pensées, où les horloges sonnent le bonheur avec une plus profonde et plus significative solennité» (Baudelaire, 1975: 302) ${ }^{41}$.

Pero, como ocurría en «La chambre double» (y es lo habitual en el ánimo y en la poesía de Baudelaire), la dicha y la esperanza y este tiempo detenido duran poco porque, como se pregunta el poeta, de nuevo de forma retórica: «Combien comptons nous d'heures remplies par la jouissance positive, par l'action réussie et décidée? Vivrons-nous jamais, passerons-nous jamais dans ce tableau qu'a peint mon esprit, ce tableau qui te ressemble?» (Baudelaire, 1975: 303) ${ }^{42}$.

En sus Journaux intimes Baudelaire dejaba testimonio biográfico del claro aviso que le daba su cuerpo de la enfermedad mental que lo arrasaría cinco años más tarde: «J'ai cultivé mon hystérie avec jouissance et terreur. Maintenant j'ai toujours le vertige, et aujourd'hui 23 janvier 1862, j'ai subi un singulier avertissement, j'ai senti passer sur moi le vent de l'aile de l'imbécilité.» (1975: 668) ${ }^{43} \mathrm{El}$ temor, la urgencia por solucionar sus asuntos y culminar algunos de sus planes vitales y literarios podrían haber dado lugar a numerosas entradas sobre el tiempo en estas páginas. Y, sin embargo, no es así. En estas páginas solo aparece una referencia a la pesadilla del tiempo (ya sin mayúsculas) y sus remedios (estos sí peraltados en la tipografía), con la introducción del Trabajo junto al Placer:

À chaque minute nous sommes écrasés para l'idée et la sensation du temps. Et il n’y a que deux moyens pour échapper à ce cauchemar, - pour l'oublier: le Plaisir et le Travail. Le Plaisir nous use. Le Travail nous fortifie. Choissons.

Plus nous nous servons d'un de ces moyens, plus l'autre nous inspire de répugnance. (Baudelaire, 1975: 669) $)^{44}$.

40 «siempre la misma hora, una hora dilatada, solemne, inmensa como el espacio, sin divisiones de minutos ni segundos, una hora inmóvil que no está marcada en los relojes y, sin embargo, leve como un suspiro, rápida como una ojeada.» (Baudelaire, 1999: 67).

${ }^{41}$ «Sí, en esa atmósfera resultaría el vivir grato; allí, donde las horas, más lentas, contienen más pensamientos, donde los relojes dan las horas de la dicha con más significativa y honda solemnidad.» (1999: 72).

42 «desde el nacimiento hasta la muerte, ¿con cuántas horas contamos?; con cuántas horas llenas por el goce positivo, por la acción lograda y decidida? ¿Viviremos alguna vez, entraremos alguna vez en ese cuadro que ha pintado mi espíritu, en ese cuadro que se te parece?» (1999: 73).

43 «He cultivado mi histeria con delectación y espanto. Ahora sufro siempre vértigo, y hoy, 23 de enero de 1862, he tenido un aviso singular, he sentido pasar sobre mí el viento del ala de la imbecilidad.» (Baudelaire, 1994: 115).

${ }^{44}$ La idea y la sensación del tiempo nos va aplastando minuto a minuto. Y sólo hay dos medios de escapar a esta pesadilla -para olvidarla-: El Placer y el Trabajo. El Placer nos desgasta. El Trabajo nos fortalece. Elijamos.

Cuanto más echamos mano de uno de estos dos medios, tanto mayor es la repugnancia que el otro nos inspira. 
220 Tropelías. Revista de Teoría de la Literatura y Literatura Comparada, número extraordinario 1 (2017) Miguel Ángel Muro

Y Baudelaire concluye su reflexión sobre el tiempo de forma práctica y algo prosaica (o quizá estoica, como quiere Poulet): «On ne peut oublier le temps qu'en s'en servant. Tout ne se fait que peu à peu.» (Baudelaire, 1975: 669) ${ }^{45}$, muy lejos del satanismo y del Don Juan en los infiernos.

\section{Bibliografía}

BAudelaire, Ch. (1975): Oeuvres complètes. I. Texte établi, présenté et anoté par Claude Pichois. Paris, Galimard.

(1994): Escritos íntimos. Introducción, traducción e índices de Francisco Torres Monreal. Murcia, Universidad de Murcia, pp. 9-51.

(1995): Las flores del mal. Edición bilingüe de Alain Verjat y Luis Martínez del Merlo. Traducción de Luis Martínez del Merlo. Madrid, Cátedra.

(1999): El esplín de Paris (Pequeños poemas en prosa). Traducción, introducción y notas de Francisco Torres Monreal. Madrid, Alianza Editorial.

Benjamin, W. (2002): Charles Baudelaire, un poète lyrique à l'apogée du capitalisme. Trad. Jean Lacoste. Paris, Payot et Rivages.

Del Prado BiezMA, J. (2011): «La temporalidad problemática del poema», en J. M. LosAdA GoyA, ed. general, Tiempo, texto e imagen. Temps, text et image. Actas del XIX Coloquio de la Asociación de Profesores de Francés de la Universidad Española (APFUE). Madrid, pp. 27-61.

DURAND, G. (1982): Las estructuras antropológicas de lo imaginario. Introducción a la arquetipología general. Madrid, Taurus.

GARCÍA JAMBRINA, L. (2000): «Prólogo» a Pere Gimferrer, Marea solar, marea lunar. Selección de Pere Gimferrer. Introducción y edición de Luis García Jambrina. Salamanca: Ediciones de la Universidad de Salamanca, Patrimonio Nacional.

Muro, M. Á. (2014): «El “tiempo del alma”. Consideraciones sobre la concepción sicológica del tiempo en el relato actual», en A. Miguel SÁEZ DE URABAin, R. GonZÁLEZ GonZÁLEZ, coords, Semiótica e historia. Sentidos del tiempo. Universidad de Burgos, pp. 249-262.

PedraZA JimÉneZ, F. B. - RodríGUEz CÁCERES, M. (1982), Manual de literatura española. VI. Época romántica. Tafalla, Cénlit Ediciones.

Poulet, G. (1949): Études sur le temps humaine. Paris: Plon.

Schlossman, B. (2011): «Baudelaire et le temps: l'allégorie de la Madone», en J. M. LosADA GoyA, ed. general, Tiempo, texto e imagen. Temps, text et image. Actas del XIX Coloquio de la Asociación de Profesores de Francés de la Universidad Española (APFUE). Madrid, pp. 685692.

SochorCOVÁ, V. (2011): «L'Ennemi de Baudelaire. Le temps comme une des composantes du spleen baudelairien», Études Romanes de Brno, 32/ 1, pp. 85-91.

45 «Sólo podemos olvidarnos del tiempo sirviéndonos de él. No hay nada que no se haga poco a poco.» (1994: 116). 